\title{
Internal Factors that Stimulates Business Startups in Southern Nigeria
}

\author{
Christabel D. Brownson
}

\begin{abstract}
In the face of unpredictable business environment, epileptic power supply, unstable government policies, poor infrastructural facilities, poor market network, inadequate capital among other factors affecting the Nigerian business environment which hinders motivation and has a great limitation to the functionality and development of entrepreneurship yet businesses are still being established. Hence, the aim of this study is to identify the internal factors that motivate such entrepreneurs in starting up businesses in Southern Nigeria despite the above challenges. Using a descriptive study, seventy one entrepreneurs were investigated. Findings revealed that passion, the desire to do something pioneering and innovative, and the feeling of accomplishment were the major factors that motivate the entrepreneurs in this context. Hence, government agencies and other empowerment institutions should take note of these factors if entrepreneurship is to be fostered.
\end{abstract}

Index Terms - Entrepreneurs, Entrepreneurship, Motivation, Startups.

\section{INTRODUCTION}

Entrepreneurship plays a very significant role in the development of the economy of any nation. However, the current economic recession which has led to unexpected variation in the social, technological, economic and the political environment has made the competition to become so deep thereby compelling the business environment to be very unpredictable to the extent that only extremely motivated, brave, inventive and greatly skilled entrepreneurs still have the zeal to go into entrepreneurship taking advantage of the erratic changes therein to survive [28]. Entrepreneurs despite being the life wire of any economy are in Nigeria faced with many challenges such as inadequate capital, deficiency in experience, uneven power supply, stiff competition, unfavorable government policies and harsh banking polices for securing loans (ibid.). Scholars have pointed out that factors such as poor infrastructural facilities, poor market network and the absence of needed motivation in terms of enabling environment and lack of stable government policies as regards business startup operations has a great limit to the functionality and development of Entrepreneurship [1], [9]. Despite these changes, several businesses are still established daily with optimism and strong will to survive [28]. It is against this background that this study seeks to identify the internal factors that motivate entrepreneurs in

Published on July 13, 2020.

Christabel D. Brownson, Akwa Ibom State University, Nigeria.

(corresponding e-mail: christabelbrownson@yahoo.com) the South-South Region of Nigeria to startup despite these challenges.

\section{FACTORS THAT STIMULATES BUSINESS STARTUPS}

Scholars have identified several factors that motivate an entrepreneur to startup a business. Such factors have been classified into internal and external factors. The internal factors are; Educational background, occupational experience, desire to do something pioneering and innovative, desire to work freely and independently and family background while external factors include; assistance from government, assistance from financial institutions, availability of technology, encouragement from big businesses, financial assistance from non-governmental sources, heavy demand for product and availability of raw materials among others [35] [36]. Gangadhararao [10] classified such factors into three groups namely: entrepreneurial ambitions, compelling reasons, and facilitating factors. According to him, entrepreneurial ambition influences an individual to undertake entrepreneurial activities such ambition includes making money, continuing family business, securing selfemployment, fulfilling the desire of self/wife/parent to make independent living and gaining social prestige. He asserted that Compelling reasons included unemployment, dissatisfaction with the previous job, making use of idle funds and revival of sick units started by fathers. Lastly, he pointed out that the facilitating factors that influences an individual to start up includes success stories of entrepreneurs, previous employment in the same or other line of activity, property inherited, property acquired, encouragement from family members and encouragement from relatives and friends. Staff [38] on the other hand identified five factors that stimulates business startups in individuals and such factors are; passion, self-reliance, feeling of accomplishment, personal growth and sense of control. The following internal factors will be considered in this paper.

\section{INTERNAL FACTORS}

\section{A. Educational Background}

Education is considered a key constituent of the human capital needed for business success [41] as it supports ones inclination to innovate [22]. Studies have proposed that highly educated individuals are more likely than less educated individuals to found new businesses [19]. Empirical evidence have shown that advance education is 
strongly related with entrepreneurial entry as such, belonging to higher or lower educational group has a positive impact on being self-employed [29]. However, Brownson [4] in her study of differences in factors that determines entrepreneurial behavior found that education is not a determinant of entrepreneurial behavior.

\section{B. Occupational Experience}

Authors have pointed out that practical experiences seem to be strongly supportive for entrepreneurial activities [40]. Multiple forms of work experience are important for supporting and boosting entrepreneurship. Staw [39] asserts that experience is the best predictor of business success, especially when the new business is related to earlier business experiences. Most successful entrepreneurs not only possess certain personal characteristics, they have usually served as apprentices within the framework of a small business, giving them relevant experience in the business environment. Typically, this experience is gained from parents, role models, or job experiences in small organizations. Exposure to a variety of experiences and opportunities provides a safe testing ground for the potential entrepreneur. Khadim and Choudhury [15] also found experience as one of the factors that motivates entrepreneurs to startup.

\section{Family background}

An ongoing influence for the entrepreneur is the influence of family background and parental role models. Krueger [17] asserted that a family firm should strongly influence its family members in their perceptions of entrepreneurship. Many researchers have indicated that prior family business exposures constitute a powerful socializing influence on the values, mindset, and behaviours people adopt over the course of their lives [5]. There exist a strong body of evidence that links entrepreneurs to parents who are themselves either self-employed or entrepreneurs. Scott and Twomey [34] reported a link between parent role and the preference for self-employment. Panchal and Dua [25] found family interest and background as one of the motivational factors to startup. Rajesh [26] study in Tamilnadu found that $74 \%$ of the respondents opined that to fulfill the ambition of parents was their motivational factor to start the unit whereas majority that is $79 \%$ of the respondents opined that the family members are the subsidiary motivation to start the unit. Subramanian [42] found family factors as the main motivating factor for entrepreneurs to startup in Tirunelveli District.

\section{Desire to work freely and independently}

Extant research has found that Independence and willingness to be free of any control or to become one's own boss is a motivating factor for one to start a business [6], [11], [40], [14]. Schwartz [32], Chakraborty and Barman [7] and Khadim and Choudhury [15] found the desire to be independent as one of the major factors motivating business startups in their studies. On the other hand, entrepreneurs in India were most strongly motivated by the desire for autonomy [3]. Cromie [8] found the need for independence as an important motivating factor for women entrepreneurs.

\section{E. Passion}

Enthusiasm though otherwise referred to as passion has been identified as a core characteristic of great wealth creators [21] and the most observed phenomenon of the entrepreneurial process [37]. Passion is required for entrepreneurial activities, it is the power to motivate entrepreneurs to startup as such, every successful entrepreneur must have a passion that drives them forward [45]. Passion and eagerness for work aids entrepreneurs to survive through monetary barriers and other difficulties [28]. Passion is pertinent in the entrepreneurship scenery because it propels entrepreneurs to face utmost uncertainty and lack of resource [43]. Although passion has been identified as important for the business creation process and the running of a business, it has received very little empirical attention from researchers [2], [27] only a few have examined and found passion as a key motivator that influences business startup [20], [44] and [46].

\section{F. Feeling of accomplishment}

Feeling of accomplishment is an important motivational factor for stimulating individuals to startup in business. Khanka's [16] study revealed the need for economic achievement as one of the primary motivators of the respondents he investigated. Prior research has also found the feelings of accomplishment as a notable and major factor in the stimulating individuals for business startups [32], [33],[15].

\section{G. Desire to do Something Pioneering and Innovative}

Innovativeness is an attitude of favouring new ideas to things and divergent thinking [18]. Innovativeness is associated with a person's willingness and interest to look for novel ways of action [27]. Innovativeness has been one of the core concepts of Schumpeter's approach to entrepreneurship and has been found to significantly correlate with entrepreneurial behaviour [27]. Mourdoukoutas and Papadimitriou [24] associated innovativeness with entrepreneurship.

\section{BUSINESS STARTUPS}

Business startup is sometimes referred to as entrepreneurial behavior [31]. A startup is a company that is in the first stage of its operations and are usually funded by their entrepreneurial founders as they attempt to capitalize on developing a product or service for which there believe there is a demand. Brownson [4] used startup businesses between 1-5yrs given the definition of an entrepreneur by Hornaday and Aboud, [12]; Hornaday and Bunker, [13]; and Robinson et al., [30]. Hence, those whose businesses are between $0-5 y$ rs are considered in this study. 


\section{RESEARCH METHOD}

A purposive sampling method was used with a structured questionnaire to collect data from 100 targeted respondents in Akwa Ibom State a state in Southern Nigeria. However, a total of 71 data from the respondents were retrieved with no errors and were used for the descriptive analysis of the data.

\section{ANALYSIS}

The aim of this study was to examine the internal factors that motivate entrepreneurs in Southern Nigeria in Starting up. From the field work, below is the analysis of the factors investigated.

TABLE 1: INTERNAL FACTORS THAT STIMULATES BUSINESS STARTUP IN

\begin{tabular}{|l|c|c|c|c|}
\hline \multicolumn{1}{|c|}{$\begin{array}{c}\text { Internal } \\
\text { Motivating } \\
\text { Factors }\end{array}$} & $\begin{array}{c}\text { HMF } \\
\text { Motivhest } \\
\text { Factor) }\end{array}$ & $\begin{array}{c}\text { MMF } \\
\text { Moderate } \\
\text { Motivating } \\
\text { Factor) }\end{array}$ & $\begin{array}{c}\text { LMF } \\
\text { (Less } \\
\text { Motivating } \\
\text { Factors) }\end{array}$ & TOTAL \\
\hline $\begin{array}{l}\text { Educational } \\
\text { Background }\end{array}$ & $28(39 \%)$ & $26(37 \%)$ & $17(24 \%)$ & $\begin{array}{c}\mathbf{7 1} \\
(\mathbf{1 0 0 \%})\end{array}$ \\
\hline $\begin{array}{l}\text { Occupational } \\
\text { Experience }\end{array}$ & $11(15 \%)$ & $31(44 \%)$ & $29(41 \%)$ & $\begin{array}{c}\mathbf{7 1}(\mathbf{1 0 0} \\
\mathbf{\%})\end{array}$ \\
\hline $\begin{array}{l}\text { Family } \\
\text { Background }\end{array}$ & $14(20 \%)$ & $33(46 \%)$ & $24(34 \%)$ & $\begin{array}{c}\mathbf{7 1} \\
(\mathbf{1 0 0 \%})\end{array}$ \\
\hline $\begin{array}{l}\text { Passion } \\
\text { Taf }\end{array}$ & $62(87 \%)$ & $9(13 \%)$ & $\begin{array}{c}\mathbf{7 1} \\
(\mathbf{1 0 0 \%})\end{array}$ \\
\hline $\begin{array}{l}\text { Feeling } \\
\text { Accomplishme } \\
\text { nt }\end{array}$ & $52(73 \%)$ & $14(20 \%)$ & $5(7 \%)$ & $\begin{array}{c}\mathbf{7 1} \\
\mathbf{( 1 0 0 \% )}\end{array}$ \\
\hline $\begin{array}{l}\text { Desire to do } \\
\text { something } \\
\text { pioneering and } \\
\text { innovative }\end{array}$ & $60(85 \%)$ & $5(7 \%)$ & $6(8 \%)$ & $\begin{array}{c}\mathbf{7 1} \\
\mathbf{( 1 0 0 \% )}\end{array}$ \\
\hline $\begin{array}{l}\text { Desire to work } \\
\text { freely and } \\
\text { independently }\end{array}$ & $16(22 \%)$ & $31(44 \%)$ & $24(34 \%)$ & $\begin{array}{c}\mathbf{7 1} \\
\mathbf{( 1 0 0 \% )}\end{array}$ \\
\hline
\end{tabular}

Table 1 above shows the internal factors that stimulates business startup in Southern (Akwa Ibom State) Nigeria. The analysis reveals that on educational background as an internal factor that motivates an individual to startup a business, Some respondents were to an extent highly motivated as shown by the high percentage $(39 \%)$ of the responses, some $(37 \%)$ were moderately motivated while only a few (24\%) were less motivated by their educational background to start up their own business. On occupational experience, majority of the respondents were moderately motivated to startup as shown by the high percentage (44\%) of responses given, some $(41 \%)$ were less motivated by their occupational experience, while only a few (15\%) were highly motivated by their occupational experience to startup.

On the analysis of family background as an internal motivating factor, majority of the respondents were moderately motivated to startup as shown by the high percentage $(46 \%)$ of responses given, some were less $(34 \%)$ motivated by their family background, while only a few (20\%) were highly motivated by their family background to startup their businesses. On the analysis of passion as an internal motivating factor, majority of the respondent were highly motivated by this factor as shown by the high percentage $(87 \%)$ of responses given while only a few $(13 \%)$ of them were moderately motivated by passion to startup their businesses.

The analysis on the feeling of accomplishment as an internal motivating factor showed that majority of the respondents were highly motivated as shown on table 1by the high percentage $(73 \%)$ of responses given, some $(20 \%)$ were moderately motivated while only a few $(7 \%)$ were less motivated by their feeling of accomplishment to startup their own businesses. Analysis on the factor the desire to do something pioneering and innovative showed that majority $(85 \%)$ of the respondents were highly motivated by this factor, a small number $(7 \%)$ of them were moderately motivated as well as a few (8\%) being less motivated by this factor to start up their own business. The last factor analyzed being the desire to work freely and independently showed that majority (44\%) of the respondents were moderately motivated by the factor to start up their business, some (34\%) were less motivated and a few (22\%) were highly motivated by this factor to startup.

On the whole, the analysis shows that to a large extent entrepreneurs in Southern Nigeria most specifically Akwa Ibom State in this context are highly motivated by Passion $(87 \%)$, desire to do something pioneering and innovative (85\%), and the feeling of accomplishment (73\%) to start up their businesses while being moderately motivated by family background (46\%), occupational experience/desire to work freely and independently (44\%) and educational background $(37 \%)$.

\section{DISCUSSION OF FINDINGS}

The aim of this study was to examine the internal factors that stimulate business startup in Southern Nigeria using Akwa Ibom State being one of the states in southern Nigeria as a case study. From the analysis above, seven factors were examined and the findings are here discussed.

\section{A. Educational background}

The result of the analysis showed that some respondents were highly (39\%) motivated by this factor to startup while some were moderately (37\%) motivated to startup. This implies that educational background is an important motivating factor that will stimulate an individual to startup. This finding aligns with Storey's [41] assertion that Educational background is a key constituent that stimulates an individual to innovate and startup. The finding also aligns with extant research that Educational background is a positive motivator and strongly relates to business startups [29]. Although Education is important in stimulating business startup, it is not a strong determinant of entrepreneurial behavior as stated by Brownson [4].

\section{B. Occupational Experience}

The result revealed that Occupational Experience is a moderate $(44 \%)$ and less $(41 \%)$ motivating factor that stimulates an individual to startup. This implies that occupational experience is not a strong motivating factor but 
only a moderate motivating factor for business startups. This findings contradicts extant research that posits that occupational experience is the best predictor of entrepreneurial behavior [39] and strongly supportive of business startups [40].

\section{Family Background}

Like occupational experience, the result also shows that family background is a moderate (46\%) and less (34\%) motivating factor that stimulates an individual to startup. This implies that family background is not a strong motivating factor but a moderate motivating factor for business startup. This finding contradicts with extant research that posits that family background is a main [42] and strong motivating factor [26] for stimulating individuals to startup.

\section{Desire to work freely and independently}

The result of the analysis showed that the desire to work freely and independently is a moderate (44\%) and less (34\%) motivating factor that stimulates business startup in individuals. It therefore means that the desire to work freely and independently is not a strong motivating factor but a moderate motivating factor for business startup stimulation. The findings contradicts extant research that posits that the desire to work freely and independently is a strong [3], major $\{[7],[15]\}$ and important [8] motivating factor for stimulating business startup.

\section{E. Passion}

The result of the analysis showed that passion is a high (87\%) motivating factor that stimulates business startup in individuals. It implies that passion is a key, strong and important internal factor that aids in stimulating individuals to startup. The findings aligns with extant research that asserts that passion is required and pertinent for entrepreneurial action ([45], [43]) and that it is a key motivator to influence business startup activities ([44], [46]).

\section{F. $\quad$ Feeling of Accomplishment}

The result indicated that feeling of accomplishment is a high $(73 \%)$ motivating factor that stimulates business startup in individuals in Southern Nigeria. It implies that the feeling of accomplishment is an important and strong internal factor that aids in stimulating individuals to startup. The findings align with prior research that states that feeling of accomplishment is a primary [16] notable and major motivating factor to stimulate business startup activities [15].

\section{G. Desire to do something pioneering and innovative}

The result indicated that the desire to do something pioneering and innovative is also a high motivating factor that stimulates business startup in individuals in Southern Nigeria. It implies that the Desire to do something pioneering and innovative is a key, important and strong internal factor that aids in stimulating individuals to startup. The findings align with prior research that states that, the desire to do something pioneering and innovative significantly relates with entrepreneurial behavior and has a strong link with the start of the venture of the entrepreneurs investigated [27], [24].

\section{CONCLUSION}

This paper sought to examine the internal factors that stimulate business startups in Southern Nigeria using Akwa Ibom State being one of the States in Southern Nigeria as an Example. The findings shows that despite various factors that motivate individuals to start up, three key influencing factors found in this contexts are Passion (87\%), desire to do something pioneering and innovative $(85 \%)$, and the feeling of accomplishment $(73 \%)$. Hence, for any individual to startup, these three key factors must be presence to stimulate them. For governmental agencies who are championing the case for business startup and funding of individuals, they should be able to observe that individuals funded to startup possess these key factors so that, the empowerment provided will not be wasted but that they will be reassured that since such individuals possess those three factors it therefore implies that they will forge ahead to establish and to sustained the businesses they have been empowered to start. Further studies could replicate this study in their context as context specific factors may likely be involve in the stimulation of individuals towards business startups.

\section{REFERENCES}

[1] Agboli, M. and Ukaegbu, C. (2006) Business Environment and Entrepreneurial Activity in Nigeria: Implications for Industrial Development, Journal of Modern African Studies, 44, 1 (2006), pp. $1-30$.

[2] Baum, J. R. and Locke, E. A. (2004) The Relationship of Entrepreneurial Traits, Skill, and Motivation to Subsequent Venture Growth, Journal of Applied Psychology, Aug2004, Vol. 89 Issue 4, p587-598, 12p.

[3] Benzing, C. and Chu, H. M. (2005) Entrepreneurial Behavior in Andhra Pradesh, India, Proceedings of the Association of Global Business 2005, Miami Beach.

[4] Brownson, C. D. (2014) Does Constituent of Entrepreneurial Culture differ in Individuals? International Journal of Small Business and Entrepreneurship Research, Vol.2, No.2, pp.22-27, June 2014 Published by European Centre for Research Training and Development.

[5] Carr, J. C. and Sequeira, J. M. (2007) Prior Family Business Exposure as intergenerational Influence and Entrepreneurial Intent: A Theory of Planned Behaviour Approach, Journal of Business Research, Oct2007, Vol. 60 Issue 10, p1090-1098, 9p.

[6] Carter NM, Gartner WB, Shaver KG, Gatewood EJ. (2003) The Career Reasons of Nascent Entrepreneurs, Journal of Business Venturing 18(1), 13-39.

[7] Chakraborty, D. and Barman, R. (2014) A Study on Impact of Motivational Factors on the Growth of Rural Entrepreneurs of Assam, IOSR Journal of Business and Management, 16(3), 71-80.

[8] Cromie, S. (1985) The Entrepreneurial Personality: A Few Ghosts Laid To Rest? International Small Business Journal, Vol. 3, pp. 43 53.

[9] Franceis, P., Lapin, D. and Rossiasco, P. (2011) Securing Development and Peace in the Niger Delta: A Social and conflict analysis for change, United State of America: Woodrow Wilson International Center for Scholars.

[10] Gangadhara Rao, N (1986), Entrepreneurship and Growth of Enterprise in Industrial Estate, Deep \& Deep Publications, New Delhi, 1986, p. 131.

[11] Gitile Naituli, Francis N. and Wegulo, Bertha Kaimenyi. (2008) Entrepreneurial Characteristics among Micro and Small- Scale 
Women Owned Enterprises in North and Central Meru Districts, Kenya. Paper presented at the Global Imaging Markets Conference at Delhouse, University, Nova Scotia, Canada.

[12] Hornaday, J. \& Aboud, J. (1971) Characteristics of Successful Entrepreneurs, Personnel Psychology, 24, 141-153.

[13] Hornaday, J. \& Bunker, C. (1970) The Nature of the Entrepreneur, Personnel Psychology, 23, 47-54.

[14] Kalyani, Brinda. P. R \& Kumar, Dileep M., (2011) "Motivationa Factors, Entrepreneurship and Education: Study with reference to women in SMEs," Far East Journal of Psychology and Business, Far East Research Centre, vol. 3(2), pages 14-35, June.

[15] Khadim Md Ekbal Hussain and Choudhury Soma Roy Dey (2018) Motivational Factors of Entrepreneurship in Micro and Small Enterprises: An Empirical Study in Cachar District of Assam, The Research Journal of Social Sciences, September 2018 volume 9 number 9 .

[16] Khanka, S. S. (2009), Motivational Orientation of Assamese Entrepreneurs in the SME Sector, Journal of Entrepreneurship, 18(2), 209-218.

[17] Krueger, N. F. (1993) "Growing Up Entrepreneurial?" Developmental Consequences of Early Exposure to Entrepreneurship. Academy of Management Best Papers Proceedings, 1993, p80-84, 5p.

[18] Krueger, N. (2003) The Cognitive Psychology of Entrepreneurship. In Z.J. Acs and D.B. Audretsch (eds.), Handbook of Entrepreneurship Research, 105-140, Great Britain: Kluwer Academic Publishers.

[19] Lee, S. Y.; Florida, R. and Acs, Z. J. (2004) Creativity and Entrepreneurship: A Regional Analysis of New Firm Formation Regional Studies, Nov2004, Vol. 38 Issue 8, p879-891, 13p

[20] Littunen, H. 2000. Entrepreneurship and the characteristics of the entrepreneurial personality. University of Jyväskylä, School of Business and Economics Centre for Economic Research. Research paper.

[21] Locke, E. A. (2000). The Prime Movers, New York: Amacom

[22] Minniti, M., Bygrave, W. and Autio E. (2005) Global Entrepreneurship Monitor - 2004 Executive Report. London: Babson College and London Business School.

[23] Morris, M. and Schindehutte, M. (2005) Entrepreneurial Values and the Ethnic Enterprise: An Examination of Six Subcultures, Journal of Small Business Management, Oct2005, Vol. 43 Issue 4, p453-479, $27 \mathrm{p}$.

[24] Mourdoukoutas, P. and Papadimitriou, S. (2002) Nurturing Entrepreneurship: Institutions and Policies Westport, Conn.: Quorum Books.

[25] Panchal, R. \& Dua, K. (2013), A Study On Motivational Factors for Becoming The Women Entrepreneur in Haryana (India), Abhinav International Monthly Refereed Journal of Research In Management \& Technology, 2, 72-78.

[26] Rajesh, V. (2012), Entrepreneurship in Small Scale Industrial Units, Doctoral Dissertation, Bharathiar University, Chennai.

[27] Rauch, A. and Frese, M. (2007) Let's put the Person back into Entrepreneurship Research: A Meta-analysis on the Relationship between Business Owners' Personality Traits, Business Creation, and Success, European Journal of Work \& Organizational Psychology, Dec2007, Vol. 16 Issue 4, p353-385, 33p.

[28] Opafunso, Z. O. and Okhankhuele, O. T. (2014) Motivation as a Factor Responsible for Entreprneurial Growth in Nigeria: A case Study of Export Logistics Limited, Akure, Nigeria, Mediterranean Journal of Social Sciences, Vol.5 No.4, March 2014, pp.166-173 pg. 8.

[29] Robinson, P. B. and Sexton, E. A. (1994) The Effect of Education and Experience on Self-Employment Success, Journal of Business Venturing 9(2):141-156 DOI: 10.1016/0883-9026(94)90006-X.

[30] Robinson, P. B., Stimpson, D. V., Huefner, J. C. and Hunt, H. K (1991) An Attitude Approach to the Prediction of Entrepreneurship, Entrepreneurship: Theory \& Practice, Summer91, Vol. 15 Issue 4, p13-31, 19p.

[31] Samuelsson, M. and Davidsson, P. (2009) Does Venture Opportunity Variation Matter? Investigating systematic process differences between innovative and imitative new ventures, Small Business Economics, Aug2009, Vol. 33 Issue 2, p229-255, 27p.

[32] Schwartz, E., (1976). Entrepreneurship: A New Female Frontier, in Journal of Contemporary Business, Winter, 47-76.
[33] Scott, C.E. (1986). Why More Women Are Becoming Entrepreneurs, Journal of Small Business Management. Vol. 24 (4), 37-44.

[34] Scott, M.G., and Twomey, D.E (1988) "The Long Term Supply of Entrepreneurs: Students' Career Aspirations in Relation to Entrepreneurship," Journal of Small Business Management (October), $5-13$.

[35] Sharma R.A (1980), Entrepreneurial Change in Indian Industry, Sterling Publishers, New Delhi.

[36] Sharma, P.N (1987), Development Banks and the New Entrepreneurship in India, National Publishing House, New Delhi.

[37] Smilor, R. W. (1997) Entrepreneurship: Reflections on a subversive activity. Journal of Business Venturing, 12, 341-346.

[38] Staff, W. G. (2017) 5 Motivational Factors that Drive People Towards Entrepreneurship, https://wealthygorilla.com/5-motivational-factors-thatdrive-people-towards-entrepreneurship/ Retrived 14/4/2020.

[39] Staw, B. M. (1991). Psychological Dimensions of Organizational Behavior. Sydney: MacMillan Timmons.

[40] Stefanovic, Ivan, Prokic Sloboda, and Rankovic Ljubodrag (2010) Motivational and Success Factors of Entrepreneurs: The Evidence from a Developing Country, Zb. rad. Ekon. fak. Rij. 2010 vol. 28, sv. 2, 251-269.

[41] Storey, D.J. (1994) Understanding the Small Business Sector, London: Routledge, 1994.

[42] Subramanian, S. (2018) Motivational Factors to Become an Entrepreneur, International Journal of Management Research \& Review, IJMRR/July 2018/ Volume 8/Issue 7/Article No-2/9-14

[43] Timmons, J. A. (2000): New Venture creation: Entrepreneurship 2000 (5thed.). Homewood, IL: Irwin. In J.R Baum and E. A. Locke (2004): The Relationship of Entrepreneurial traits, skill and motivation to subsequent venture growth. USA: copyright by the American Psychological Association. In journal of Applied Psychology. Vol. 89, No. 4, p. 588.

[44] Uddin, Md. Mahi; Chowdhury, Mustafa Manir and Ullah Md. Maruf (2015) Barriers and Incentives for Youth Entrepreneurship Start-Ups: Evidence from Bangladesh, Global Journal of Management and Business Research: A Administration and Management Volume 15 Issue 4 Version 1.0 Year 2015

[45] Yimamu, Nadire (2018) Entrepreneurship and Entrepreneurial Motivation Thesis Centria University Of Applied Sciences, Business Management April 2018.

[46] Yukongdi, V. (2018) Motivational Factors, Facilitators, Obstacles and Gender Differences: An Exploratory Study of Thai Entrepreneurs. PEOPLE: International Journal of Social Sciences, 4(1), 288-297. DOI-https://dx.doi.org/10.20319/pijss.2018.41.288297.

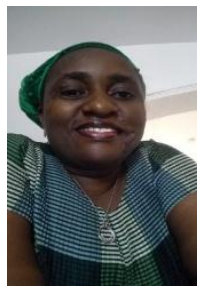

Dr. Christabel Brownson holds a B.Sc in Banking and Finance from University of Uyo, Uyo, Akwa Ibom State, Nigeria, M.Sc in Entrepreneurship and Innovation and $\mathrm{PhD}$ in Entrepreneurship both at the University of Essex, Essex, England. She is a knowledge facilitator and specializes in motivating the entrepreneurial individuals to proactive value venture creation. She is a member of the Institute of Entrepreneurs, Nigeria and an Associate of the British Advance Higher Education Academy. Her research interest cover Entrepreneurial Culture, New Venture Creation, Entrepreneurship Education, Nigerian Entrepreneurship and Policy Effectiveness. She has several publications to her credit in international journals. 